\title{
Ethnoveterinary survey of tradomedical importance of Bos taurus $L$ urine, bile and dung in Nigeria and South Africa
}

\author{
Mariam O Oyedeji-Amusa, Oladele T Ojuromi and Anofi O Ashafa* \\ Phytomedicine and Phytopharmacology Research Group, Department of Plant Sciences, University of the Free State, Qwaqwa \\ Campus. Phuthaditjhaba Private Bag X13, 9866, South Africa \\ *For correspondence: Email: ashafaat@ufs.ac.za
}

\begin{abstract}
Purpose: To evaluate the ethnoveterinary uses of cow by-products from Nigeria and South Africa. Methods: A field survey was conducted from January to September, 2015 by conducting interviews with 110 respondents who provided information in respect of the use of cow urine, bile and dung in their folk medicine in Nigeria and South Africa.

Results: Most respondents opined that urine therapy is effective in treating convulsion (50\%), viral infections (29.2\%), and rheumatic arthritis (14.6\%) in Nigeria. In South Africa respondents are of the view that urine is highly effective (28.6\%) in treating diarrhoea while $14.3 \%$ stated that urine can treat fever, sore throat, skin infections. Bile is commonly used in treating general body pain and high blood pressure in Nigeria and used for skin burns in South Africa. Cow dung is specifically used in both countries as pesticides, fertilizers, anti-toxins and treating skin infections. This study documents the ethnoveterinary uses of B. taurus by-products by traditional practitioners in Nigeria and South Africa. Conclusion: There is need for further studies to validate the therapeutic potential of these products with regards to each of the ailments listed and isolation of the bioactive compounds in African species of $B$. taurus by-products.
\end{abstract}

Keywords: Ethnoveterinary, Urine, Bile, Dung, Bos taurus, Tradomedical, Folk medicine, Field survey

Tropical Journal of Pharmaceutical Research is indexed by Science Citation Index (SciSearch), Scopus, International Pharmaceutical Abstract, Chemical Abstracts, Embase, Index Copernicus, EBSCO, African Index Medicus, JournalSeek, Journal Citation Reports/Science Edition, Directory of Open Access Journals (DOAJ), African Journal Online, Bioline International, Open-J-Gate and Pharmacy Abstracts

\section{INTRODUCTION}

In most part of the world, cow, Bos taurus is a valuable animal regarded for its nutritional value and importance in folk medicine. In rural African settings, these animal products have being used for several decades as an effective antiseptic for wounds, skin diseases, agriculture, biopesticides, pest repellents and possibly alternate energy source and bathing etc [1-3]. It is known throughout human history that indigenous people have used various materials from nature to cure illnesses and to improve their health status [4]. In terrestrial animals, products from wild as well as from domestic animals such as honey, milk, fat, bone marrow, blood, flesh, faeces, urine, skin, semen, ligaments, bones, shell, horn and feathers are used in folk medicine [1,5-6]. According to World Health Organisation (WHO), more than $80 \%$ of the developing world's rural population depend on traditional medicines for their primary health care needs $[7,8]$. Traditional medicine (TM) has a long history and it is described by WHO as the sum total of the knowledge, skill and based on theories, beliefs and experiences indigenous to different cultures, whether explicable or not, used in the maintenance of health as well as in the prevention, diagnosis, improvement or treatment of physical and mental health [7]. A traditional 
healer on the other hand is a person who is recognised by the community as someone competent to provide health care by using plant, animal and mineral substances and other methods based on social, cultural and religious practises [8]. There are strong indications that traditional health care systems are still in use by majority of the people not only in Africa but other developed countries $[7,9,10]$.

Studies have shown there is an increased interest in the use of TM in African countries [7,11-14]. Evidences have proved that cow urine therapy has medicinal potential, particularly for its use along with antibiotics for the control of bacterial infections and fight against cancers $[15,16]$. This supports cultural belief that cow byproducts could play significant role in curing terminal diseases. Cow urine is reported to be capable of treating many curable and incurable diseases and has been used extensively for many decades across continents especially among Indians $[2,17,18]$. The composition of cow urine, bile and dung has been fully described [2,17-21]. The cow dung has been used as fertilizer, cheap fuel, housing materials, insect repellent and in bio-remediation [2,3,22]. Moreover, there are over 60 species of bacteria, about 100 species of protozoans and yeasts in the dung of cow [3]. Studies on therapeutic use of cow urine, bile and dung have been neglected for a very long time when compared to plants. Hence, the present study was undertaken to document ethno-medical uses of cow byproducts among cultures in Nigeria and South Africa. The outcome is expected to fill gaps and provide more information on the use of cow byproducts by different cultures in the two countries.

\section{METHODS}

\section{Study area}

The study area comprises different ethnic cultures from Lagos, Ogun, Oyo and Kwara States in Nigeria. The indigenous people in this region are mostly Yorubas and their common language is Yoruba and its different dialects. The population of the Yorubas in South Western part is about $20-30$ million which accounts for $17 \%$ of the total population of Nigeria [23]. The South Western part is surrounded by North central and South East Geo-political zones. The Yorubas operates varied system of occupations such as farming, blacksmithing and hunting for wild life, fishing, sculpturing (Figure 1a). Thabo Mofutsanyana district is within Phuthaditjhaba of
Free State Province, South Africa. It is a Sotho town and flanked by the drama of Drankesberg and Maluti mountains (Figure 1b). The province is warehouse for storage of grains with agriculture central to its economy, while mining on the rich gold fields' reef is its largest employer. The people of the province are predominantly sesotho which accounts for 26.8 $\%$ of the total population of Free State (https://en.wikipedia.org/wiki/Free_State_ (province).

A field survey was conducted in Lagos, Ogun, Oyo and Kwara States in South Western Nigeria and Thabo Mofutsanyana district municipality of the Free State Province, South Africa. Survey was conducted from January to September, 2015 by conducting interviews with 110 respondents (58 men and 52 women). Information was collated on traditional uses and knowledge regarding the use of cow urine, bile and dung in folk medicine. These respondents are elderly people, herbalists and traditional healers within age range of 45-82 years old. The selection was purely based on their recognition as knowledgeable members of the various communities in respect of folk medicine. They provided information on the usefulness of the animal products, concoctions and the disease they cure. This study considered the preparation of remedies and administration of cow byproducts when used alone and in combinations with other plant parts. The information provided indicates how the cow by-products are used traditionally in terms of dose administered in Nigeria and South Africa. Data were analysed to determine the common diseases or ailments cured with the animal by-products and other ingredients mixed to make concoctions.

\section{RESULTS}

The respondents provided information on the use of urine, bile and dung used to cure ailments and methods of preparation and administration of dose. Of the 48 respondents from South Western Nigeria, $56.2 \%$ males and $43.8 \%$ females. Fifty per cent of the respondents use urine as the most common animal products to treat convulsion, closely followed by 14 (29.2 \%) for treating various viral infections such as measles, smallpox, chickenpox, 7 (14.6\%) for rheumatic arthritis and 6 (12.5\%) for general body pains. In South Africa, urine is commonly used to treat diarrhoea, fever, sore throat and pile, while bile is used to treat skin infection (Table 1).

It was only in Nigeria that four of the respondents agreed that mixture of cow urine and bile are prepared as concoction to treat various ailments 

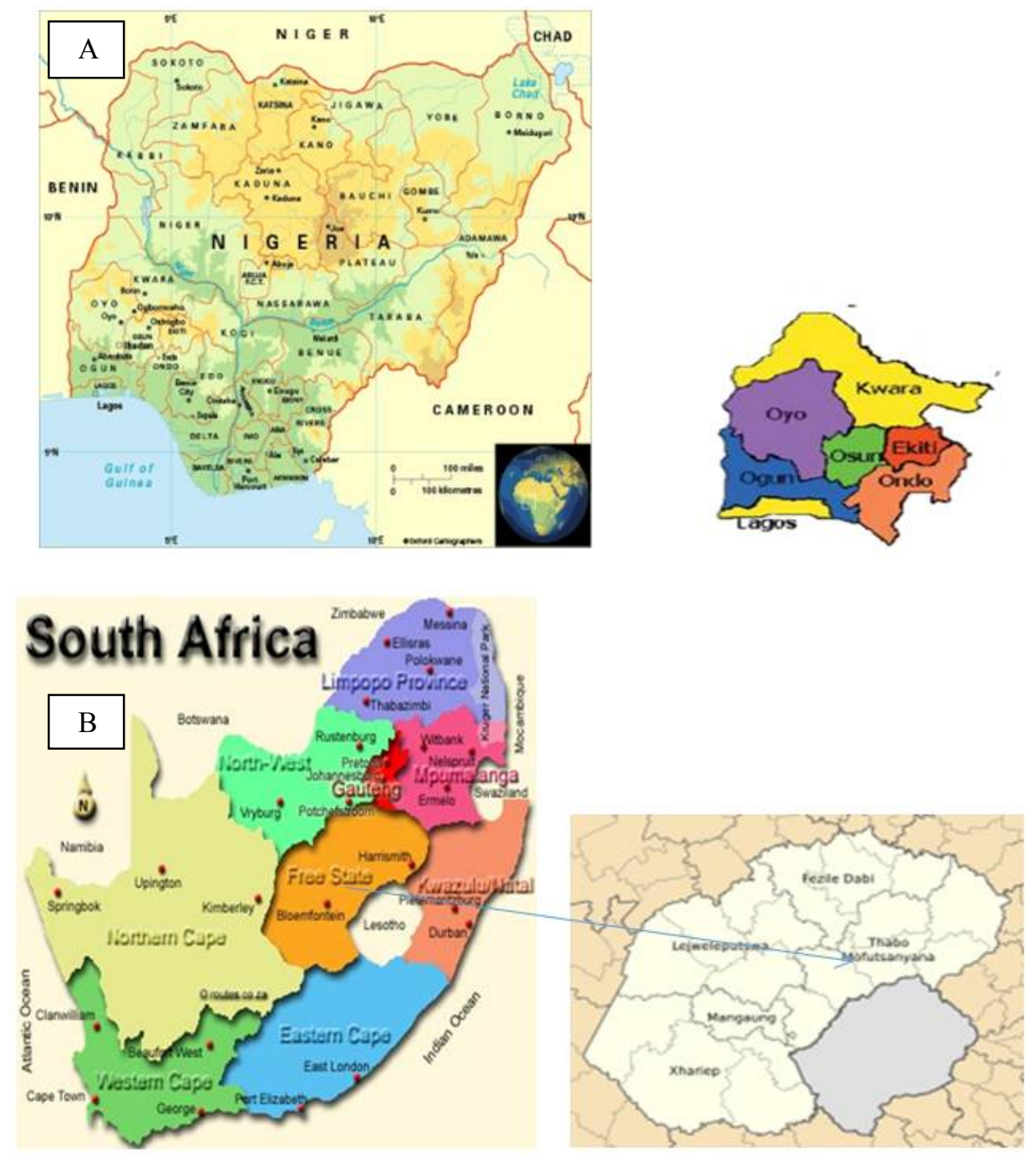

Figure 1: Map of (A) Nigeria showing the South Western states in Nigeria and (B) South Africa showing Thabo Mofutsanyana district in Eastern Free State Province

as convulsion, cough and rheumatisms by adding tobacco leaves. The study observed that preparation of remedies and administration of dosage differs from one respondent to another within the same country. In Nigeria, fresh cow urine or stored forms are prescribed in dose of 2 or 3 tablespoonful for all forms of ailments. Some of the respondents do mix cow urine with medicinal plants (Bridelia micrantha, Nicotiana tabacum) which in their opinion will improve the antimicrobial activity of the urine to treat and cure any form of diseases. There is similarity in the dosage administration from Thabo Mofutsanyana municipality, South Africa, except that there was inadequate information on the addition of medicinal plants to cow urine. In contrast to urine, bile is usually swallowed whole or mixed with other ingredients such as alligator pepper (Aframomum melegueta), alcohol, corn, lime, orange and honey to treat stomach ache, infertility and menstrual pains. Dried bile is usually applied on skin to treat any skin infection or burn. Nonetheless, it was revealed that addition of other materials with urine, bile and dung plays significant role in the therapeutics by enhancing the efficacy of the different herbal preparations (Table 2). The knowledge of folk medicine was acquired through parental heritage or probably they have an idea of the medicinal importance of some animal products and their medicinal value.

It was only in Nigeria that four of the respondents agreed that mixture of cow urine and bile are prepared as concoction to treat various ailments as convulsion, cough and rheumatisms by adding tobacco leaves. The study observed that preparation of remedies and administration of dosage differs from one respondent to another within the same country. In Nigeria, fresh cow urine or stored forms are prescribed in dose of 2 or 3 tablespoonful for all forms of ailments. Some of the respondents do mix cow urine with medicinal plants (Bridelia micrantha, Nicotiana 
Table 1: Traditional uses of cow urine, bile and dung in Nigeria and South Africa

\begin{tabular}{|c|c|c|c|}
\hline Characteristics & Urine ( \% ) & Bile ( \%) & Dung ( \%) \\
\hline Nigeria & & & \\
\hline \multicolumn{4}{|l|}{ Nigeria } \\
\hline Male & $27(56.2)$ & $21(58.3)$ & - \\
\hline Female & $21(43.8)$ & $15(41.7)$ & - \\
\hline \multicolumn{4}{|l|}{ Diseases/Ailments } \\
\hline Convulsion & $24(50.0)$ & $7(19.4)$ & - \\
\hline Rheumatism & $7(14.6)$ & - & - \\
\hline Viral infection & 14(29.2) & $5(13.8)$ & - \\
\hline General Body Pain & $6(12.5)$ & $18(50.0)$ & - \\
\hline Diabetes & - & $7(19.4)$ & $1(2.7)$ \\
\hline High Blood pressure & - & $6(16.7)$ & - \\
\hline Skin Diseases & - & $1(2.7)^{\prime}$ & - \\
\hline Pesticides & - & - & $3(50.0)$ \\
\hline Fertilizer & - & - & $1(2.7)$ \\
\hline Soap & - & - & $1(2.7)$ \\
\hline Others & $5(10.4)$ & $1(2.7)$ & - \\
\hline \multicolumn{4}{|l|}{ South Africa } \\
\hline \multicolumn{4}{|l|}{ Sex of Respondents } \\
\hline Male & $2(28.6)$ & $1(50.0)$ & $1(14.3)$ \\
\hline Female & $5(71.4)$ & $1(50.0)$ & $6(85.7)$ \\
\hline \multicolumn{4}{|l|}{ Diseases/Ailments } \\
\hline Diarrhoea & $2(28.6)$ & - & $1(14.3)$ \\
\hline Fever and ache & $1(14.3)$ & - & $2(28.6)$ \\
\hline Throat Infection & $1(14.3)$ & - & - \\
\hline Haemorrhoid/piles & $1(14.3)$ & - & - \\
\hline Skin Infection & $1(14.3)$ & $2(100.0)$ & $3(42.9)$ \\
\hline Anti-toxin & $1(14.3)$ & - & $1(14.3)$ \\
\hline
\end{tabular}

Table 2: Traditional uses of urine, bile and dung along with adjuvant in South Western, Nigeria

\begin{tabular}{ll}
\hline Diseases & Constituents Of Urine, Bile, Dung With Adjuvant \\
\hline Convulsion & Distilled urine, tobacco leaf, Crinum jagus, Bridelia micrantha \\
Fever & Urine, Allium cepa \\
Stomach pain & Urine, Croton penduliflorus \\
Sore throat & Fresh urine \\
General infection & Bile, alcohol, lemon, honey \\
Stomach pain & Bile, Aframomum melegueta \\
Infertility & Bile, lime, Citrus, honey and Harungana madagascariensis \\
Pesticide & Dung, sand, ashes \\
Haemorrhoid & Dung, Vitex grandifolia \\
\hline
\end{tabular}

tabacum) which in their opinion will improve the antimicrobial activity of the urine to treat and cure any form of diseases.

There is similarity in the dosage administration from Thabo Mofutsanyana municipality, South Africa, except that there was inadequate information on the addition of medicinal plants to cow urine. In contrast to urine, bile is usually swallowed whole or mixed with other ingredients such as alligator pepper (Aframomum melegueta), alcohol, corn, lime, orange and honey to treat stomach ache, infertility and menstrual pains. Dried bile is usually applied on skin to treat any skin infection or burn.

Nonetheless, it was revealed that addition of other materials with urine, bile and dung plays significant role in the therapeutics by enhancing the efficacy of the different herbal preparations (Table 2). The knowledge of folk medicine was acquired through parental heritage or probably they have an idea of the medicinal importance of some animal products and their medicinal value.

\section{DISCUSSION}

Traditional medicines for several decades have used materials sources from plants and animals to improve health care of the people. For many millions of people, traditional treatments and traditional practitioners are the main source of health care and sometimes the only source of health care. It is culturally acceptable and trusted by large number of people. The phenomenon of zootherapy has broad geographical distribution and historical origins. Therefore, it constitutes an 
important alternative among other therapies practiced worldwide [4,24 ]. Interestingly, large numbers of drugs have been isolated from natural sources and many are based on their use in traditional medicine $[1,4,20]$. In Africa and many parts of the world, TM has stood the test of time in both rural and urban communities.

There are strong indications that traditional health care systems are still in use by the majority of people not only in Africa but across the world $[5,8]$. This study was able to assess traditional importance of cow urine, bile and dung in the folk medicine of Nigeria and South Africa. From the various assertions of the respondents, the results of the survey is in agreement with recent reports from other countries where cow urine was confirmed to have high therapeutic effect in the treatment of various diseases $[16,17,19]$. The wound healing of cow urine was reported in Wister albino rats and the outcome of the treatment revealed that it hastened healing process [25]. In contrast, none of the respondents from the countries under study is aware of the healing potential of cow urine on wounds.

This study also shows that cow urine in Nigeria is mostly used to treat convulsion, rheumatism, viral infections (measles, smallpox, chickenpox) and general body pains in 24 (50.0 \%), 7 (14.6 $\%)$ and $6(12.5 \%)$ respectively. In contrast to South Africa, cow urine is used in the treatment of diarrhoea, fever, throat and skin infections and as anti-toxins. It was observed that the assertion of most respondents is in agreement with other studies where cow urine and the distillate were found to have healing properties, effective antimicrobial agent against Staphylococcus aureus, Escherichia coli, Pseudomonas fragi, Bacillus subtilis, Streptococcus agalactiae and Proteus vulgaris $[18,25,26]$. Moreover, another study reported anti-cancer activity of cow urine in cancer therapy [16]. In contrast to this study, respondents are very much unaware of the potency of cow urine in treating cancer both in Nigeria and South Africa respectively. Nevertheless, there is urgent need for concerted efforts to study the components of cow urine in African breeds if they contain bioactive compounds that will be potent enough in treating cancer.

It was suggested in some reports that cow urine distillate, re-distillation and residues exhibit antioxidant activity and the cow urine could be a potential source of natural antioxidant that could be of importance as supportive therapy in preventing or slowing oxidative stress related degenerative diseases $[18,22,27]$. For instance, oral administration of cow urine concoction in rats causes activation of the third complement component in the serum and this could have histamine-releasing effects and reverse the acute fall in neutrophils and monocyte counts within a couple of hours [28]. The current study also observed that some of the respondents are of the opinion that distillate urine could treat convulsion. It will be of immense benefit if this view expressed by respondents could be verified through scientific validation. Apart from curing diseases, cow urine helps in maintaining homeostasis of body where it affects certain body functions by lowering cholesterol level, improving memory, enhancing the function of the liver, slowing aging process, and destroying toxic effects of medicinal residue in the body [17].

Available information on ethno-medicinal properties of bile in TM showed that it is essential in improving liver functions, dissolving gallstones, inhibiting bacterial and viral multiplication, exhibit anti-inflammatory, anti-pyretic, anti-oxidant, anticonvulsive, anti-allergic, anti-diabetic, and antispasmodic effects [20]. Scientific evidence have shown that bile contains a wide variety of antioxidants, the most powerful ones being bilirubin, glutathione, vitamin $\mathrm{E}$ and melatonin $(\mathrm{N}-$ actyl-5-methoxytryptamine) [21]. The fact that most of the respondents agreed that bile can be used for the treatment of various ailments without scientific proof corroborates the traditional knowledge acquired by traditional healers' who practice folk medicine and supports assertion by several authors $[1,4]$. According to Wang and Carey [20], the use of pig, wild boar and human bile diluted with alcohol form artificial skin for burns and wounds several decades ago and this could support the informed use of cow bile in treating skin burns and infections in some parts of South Africa by traditional healers.

It is worth mentioning that cow dung uses in TM is mainly for pest control, fertilizers and in some instances to cure skin infection and possibly as anti-toxins when mixed with other ingredients. In a study, cow dung was found to be useful in bioremediation of pharmaceutical, pesticides and petrochemical waste [2,29-30]. Interestingly in Nigeria, cow dung was assessed for aerobic, heterotrophic bacteria and petroleum-utilizing bacteria as well as degradation potential of petroleum-utilizing bacteria isolates [31]. Some of the bacteria isolated from cow dung were identified as petroleum utilizers. Cow urine and dung has been proved to be effective, cheap and excellent bio-remediator to harmful pollutants and this support it uses in traditional medicine. It is possible that microorganisms obtained from 
cow dung may have the ability for bioremediation in laboratory and on field experiments, it can also be applied on pesticide contaminated soil and water.

\section{Limitations of the study}

The respondents reluctantly gave information on the uses of cow by-products and the survey could not cover more states in both countries.

\section{CONCLUSION}

Within the WHO African region, progress has been made in policy development and the number of African countries with traditional and complementary medicine has increased tremendously in terms of regulatory framework, code of ethics and legal framework for TM practitioners. The area of cowpathy using products such as urine, bile, milk and dung has tremendous potential in the fields of medicine and tackling environmental pollutions and this has not been exploited to the extremes. Though, traditional medicine practitioners claims are too numerous but scientific validations of those claims and assertions are required. Therefore, efforts must be made to create awareness about the important virtue of cow therapy; need for standard guidelines and database be made available to TM practitioners.

\section{DECLARATIONS}

\section{Acknowledgement}

The authors are grateful to UFS-Qwaqwa Research Committee, Directorate of Research Development at UFS and Lagos State University, Nigeria for the release of Dr Ojuromi to take up a postdoctoral position at University of the Free State. We also acknowledge the contributions of all respondents (herbalists, traditional healers and the elderly) for their support during the survey.

\section{Conflict of Interest}

No conflict of interest associated with this work.

\section{Contribution of Authors}

The authors declare that this work was done by the authors named in this article and all liabilities pertaining to claims relating to the content of this article will be borne by them.

\section{REFERENCES}

1. Alves RRN, Alves HN. The faunal drugstore: Animalbased remedies used in traditional medicines in Latin America. J. Ethnobiol. Ethnomed. 2011; 7: 9 (http://www.ethnobiomed.com/content/7/1/9).

2. Randhawa GK, Kullar JS. Bioremediation of pharmaceuticals, pesticides and petrochemicals with Gomeya/cow dung. Int. Scholar. Res. Network Pharmacol. 2011; 12: doi: 10.5402/2011/362459.

3. Chin HC, Ahmad NW, Kian CW, Kurahashi H, Jeffrey J, Kiang HS, Omar B. A study of cow dung diptera in Sentul Timur, Kuala Lumpur, Malaysia. J. Trop. Med. Parasitol. 2010; 33: 61.

4. Alves RRN, Rosa IL. Zootherapeutic practices among fishing communities in North and Northeast Brazil: $A$ comparison. J. Ethnopharmacol. 2007; 111: 103.

5. Alves RRN, Lima HN, Tavares MC, Souto WMS, Barboza $R R D$, Vasconcellos A. Animal-based remedies as complimentary medicines in Santa Cruz do Capibaribe, Brazil. BMC. Complement. Altern. Med. 2008; 9.

6. Mahawar MM, Jaroli DP. Traditional knowledge on zootherapuetic uses by saharia tribe of Rajasthan, India. J. Ethnobiol. Ethnomed. 2007; 6

7. WHO, WHO traditional medicine strategy. 2013; 20142023.

8. Alves RRN, Rosa IL. Why study the use of animal products in traditional medicines? J. Ethnobiol. Ethnomed. 2005; 1:5.

9. WHO, Traditional and Modern Medicine: Harmonishing the two approaches. Western Pacific Region. Geneva; 2000; World Health Organisation.

10. Abdullahi AA, Trends and challenges of traditional medicine in Africa. Afri. J. Trad. Complement. Altern. Med. 2011; 8(S): 115-123.

11. WHO, Traditional Medicine-Growing Needs and Potential. 2002; Geneva

12. Mander $M$, Ntuli $L$, Diederichs $N$, Mavundla $K$. Economics of the traditional medicine trade in South Africa 2007; (http://www.hst.org.za/uploads/files/chap).

13. Makundi EA, Malebo HM, Mhame P, Kitua AY, Warsame M. Role of traditional healers in the management of severe malaria among children below five years of age: the case of Kilosa and Handeni Districts, Tanzania. Malaria J. 2006; 5(58): 9.

14. Amira OC, Okubadejo NU. Frequency of complementary and alternative medicine utilization in hypertensive patients attending an urban tertiary care centre in Nigeria. BMC. Complement. Altern. Med. 2007; 7(30): 5.

15. Jain NK, Gupta VB, Garg R, Silawat N. Efficacy of cow urine therapy on various cancer patients in Mandsaur District, India-A survey. Int. J. Green Pharm. 2010; 4: 35.

16. Dhama K, Chauhan RS, Singhal L. Anti-cancer activity of cow urine: current status and future directions. Int. J. Cow Sci. 2005; 1(2): 25. 
17. Mohanty I, Senapati MS, Jena D, Palai S. Diversified uses of cow urine. Int. J. Pharm and Pharm. Sci. 2014; 6(3): 22

18. Sai KV, Lakshmana RR, Ramesh AK. Indian cow urine distillation and therapeutic uses. Mintage J. Pharm. Med. Sci. 2015; 4(1): 5.

19. Kumar S. Analysis of cow's urine for detection of lipase activity and anti-microbial properties. IOSR J. Pharm. Biol. Sci. 2013; 7(1): 8.

20. Wang DQ, Carey M. Therapeutic uses of animal biles in traditional chinese medicine: An ethnopharmacological, biophysical chemical and medical review. World J. Gastroenterol. 2014; 20 (29): 9975.

21. Tan D, Manchester LC, Reiter RJ, Qi W, Hanes MA, Farley NJ. High physiological levels of melatonin in the bile of mammals. Life. Sci. 1999; 65: 2529.

22. Mandavgane SA, Rambhal AK, Mude NK. Development of cow urine based disinfectant. Nat. Prod. Rad. 2005; 4(5): 415.

23. www.photius.com/countries/nigeria/society/nigeria_societ y_the_southern_area.html

24. Sodeinde OA, Soewu DA. Pilot study of the traditional medicine trade in Nigeria. Traffic Bull. 1999; 18(1): 40.

25. Sanganal JS, Jayakumar K, Jayaramu GM, Tikare VP, Paniraj KL, Swetha $R$. Effect of cow urine on wound healing property in Winster Albino rats. Vet. World. 2011; 4(7): 321.

26. Anami A, Kumar P, Verma A, Tanwar R. Antimicrobial activities of cow urine against various bacterial strains. Int. J. Recent. Adv. Pharm. Res. 2012; 2(2): 87.

27. Krishnamurthi K, Dutta D, Sivanesan D, Chakrabarti $T$. Protective effect of distillate and re-distillate of cow's urine in human polymorphonuclear leukocytes challenged with established genotoxic chemicals. Biomed. Envir. Sci. 2004; 17: 66.

28. Olusi SO, Ojewole JA. Evidence for complement activation following the oral administration of cow's urine concoction in rats. Afr. J. Med. Sci. 1978; 7: 83.

29. Singh $D$, Fulekar $M H$. Bioremediation of phenol by a novel partitioning bioreactor using cow dung microbial consortia. Biotechnol. J. 2009; 4(3): 431.

30. Singh D, Fulekar MH. Benzene bioremediation using cow dung microflora in two phase partitioning bioreactor. J. Hazard. Mat. 2010; 175(1-3): 343.

31. Akinde SB, Obire O. Aerobic heterotrophic bacteria and petroleum-utilizing bacteria from dung and poultry manure. World J. Microbiol. Biotechnol. 2008: 24(9): 2002. 